\title{
Legitimacy Conflicts in Indonesian Democracy: The Awakening of Civil and Political Islam in Post 411 and 212
}

\author{
Chusnul Mar'iyah \\ \{EMAIL DISINI\} \\ Department of Political Science, Universitas Indonesia
}

\begin{abstract}
Democracy is believed as a generally uncontested the ideal form of government after the fall of communism in the former USSR at the end of the decade's 1980s. In Indonesia, however, while regimes (since 1999 to 2019 elections), inspired by this form of government through free and fair elections, have been fall under constant criticism. Especially, since the Pandemic of Covid-19 outbreak around the world. After one year of the Pandemic Covid-19, the steady erosion of confidence government to tackle the Pandemic Covid-19 has become one of the major political issue on the legitimacy. Even though, the legitimacy of government has been shrinking before Pandemic C-19 because of many policies on economy, foreign workers, environment etc. Prior to Jakarta Election, there were very serious issue of religious blasphemy of $\mathrm{Al}$ Qur'an, $\mathrm{Al}$ Maidah: 51. However, the regime supported Basuki Tjahya Purnama (Ahok) the then Governor of Jakarta on the issue The incident brought the awakening of civil Islam - as civil movement- by protesting the issue. Millions Muslim people gathered in Jakarta was the moment resurgent of the civil and political Islam in the reformation era. This article will discussed the legitimacy and democracy in Indonesia post 411 and 212 which is in line with the issue of Pandemic Covid19. The contestation of government power with civil Islam, such as FPI and many Muslim groups (male and female), have been interested to be explored. The proliferation of power of oversight leads to what might called democratic competition between the electoral representative (political parties and DPR) and the elected president must contend with various form of civil oppositions or non-parliamentary opposition. The resulting rivalry is partly functions of parliamentary control versus control by civil independent society group such as FPI and others. Furthermore, this article will discuss the legitimacy of government in combating the Pandemic Covid-19, with in the era of distrust, give the space for the awakening of civil Islam and political Islam (nonparliamentary). The issue of jailing the HRS (for example: Habib Rizieq Shihab as FPI leader), followed by the issue of KM 50 gave fuel the discussion of the legitimacy of the regime whether it could be called fail state to protect the citizen or placing powerful demands of civil Islam to provide instrument for achieving legitimacy and democracy. I argue - in term of legitimacy in democracy- , there are two issue, first, "desacralization" of the representation
\end{abstract}


election, and second the growing important of legitimacy by civil society (the watchdog power).

Keyword : Government, political, Islam

\section{Introduction}

The movement for political openness and political change in Indonesia in 1998 from an authoritarian regime to a democratic regime happened. It is in line with global political developments, namely the Glasnost and Perestroika movements, the fall of the communist regime in the former USSR. In the early 1990s, the Huntington model was referred to as thirdwave democratization. The emergence of new democratic countries in Asia, Eastern Europe, Latin America, and Africa. A big project in the politics of new democracies is the succession of government through elections and resolving past gross human rights violations. Democratic theorists such as O'Donell's have linked democratic transitions to resolving past human rights violations. The extent to which democracy develops in its practical realization is interesting to study. The theory of democracy in ancient Greece is very exclusive. However, subsequent developments with criticism of feminist groups, for example, resulted in women's movements to get their representation in parliament. Similarly, democracy is suspected as a model in Western political culture that is individualistic. To what extent, then, in the culture of Muslim society can democracy be compatible? This paper investigates how democracy is realized in Indonesia after the 411 and 212 movements, especially the emergence of the power of civil Islam and or political Islam. The extent to which the issue affects the legitimacy of the government.

\section{Result and Discussion}

\subsection{Democracy Triumph or Crisis: a question of legitimacy}

The development of post-reform democracy and its development since 1998, questions arise such as is democracy triumph or crisis? Democracy as a government system is much revered, but is there a country that has successfully implemented democracy? The answer is yet nowhere achieved. However, scholars believe that democracy is considered an ideal concept, especially as the dominant political aspiration in many countries. In practice, there are still many defects; there is a paradox from Triumph and In Crisis. According to Fukuyama: have suggested that contemporary reality bears witness to the universal of democracy, at least in its liberal democratic form. (Francis Fukuyama, The End of History and the Last Men, 1992). Meanwhile, Huntington has written democracy's third wave, in which it has challenged authoritarian and militaristic regimes in Europe (Spain, Portugal) and has been invigorated, though still with uncertain outcomes, by movements of people power in developing countries such as the Phillippines, Indonesia, and Mexico (the Third Wave of Democratization in the Late Twentieth Century). At the same time, a new development in democratic theory, deliberative democracy, feminism, the Internet testifies to the renewal of the democratic ideal. In other words, democracy reaches out to the excluded groups in our society and even into cyberspace. However, the complexity of global politics nowadays - such as the globalization of capitalism and market, the issue of terrorism post 9/11 and radicalization, - brought the question of a universal model of democracy. 
Democracy, in the long history of the Greek era, was far from inclusive, keeping out slaves, women, and foreigners (Pericles) and excluding women from the ranks of democratic citizens (Rousseau). The problems occurred that the ideal democracy has never been universally accepted because of the democratic ideal out of hand, elitist and authoritarian critics. Democracy claims that the concept of eurocentrism has values on individualism, rationality, and autonomy of the individual. The assumption of democracy doesn't make it compatible with other cultures such as Islam. However, the democratic theory has been developed in the modern institution; for example, in the nation-state model, while the original of democracy from ancient Greece was in the model of city polis.

Weber offered a famous distinction between three types of legitimacy: traditional, charismatic, and rational-legal (bill Jones, et.al. Politics $U K$, page 14). The first of these rests on custom and appeals to continuity of the past. It is the principal ground by which rule through the tradition of a hereditary monarchy is justified. The second appeal is to the divinelike anointed quality of leadership; even dictators can be seen as leading charismatically, for example, having commanded obedience through their charismatic qualities. Rational-legal legitimacy rests because agreed-upon rules and agreed purposes are observed in making decisions. In reality, not all countries have leaders who are based on the quality of their charisma. State legitimacy, like in the UK, relies on tradition, which has a rational-legal character. All of his actions are based on the procedures of the rule of law issued by the parliament. Through these rules, the state uses its authority. Thus, the state can give the command to its citizens with the backing of laws and regulations.

Understanding a regime's legitimacy, the series of stages in forming a government regime begins with the general election process. The extent to which elections, one of which functions are to obtain legitimate leaders, are carried out with the principle of free and fair. The extent to which election manipulation such as money politics and transactions did not occur.

The challenge of the model democracy in practice is about the competition among the development of the political power, for example, political parties. Through modern political parties, regular elections, and the operations of pressure groups, democracy works as a mechanism, an institutional arrangement for arriving at political decisions through a competitive struggle for the people to vote. (democracy readers). Since the 2004 general election, both legislative and presidential elections were the first in Indonesian politics; American President Jimmy Carter said during a visit to the KPU that Islam and democracy are compatible. (Meeting of KPU Commissioners with Jimmy Carter and Nancy Carter at KPU Jakarta Office).

The development of democracy through elections has consequences for the authority of the regime power. The extent to which the people can accept the regime in power and submit and obey its government. According to John Lock, the legitimacy of this order is very important in the framework of being the foundation of government power. The extent to which the people can accept government policies depends on the level of legitimacy. Thus, the election gives legitimacy to the formation of a government. In the context of government, according to Weber, three categories can be considered. According to Robert Dahl, the extent to which power can be maintained depends on the level of legitimacy. If the legitimacy of a government is very low, it can cause the government's power to be in danger. (Dahl, Poliarchy, 1971, pp 124). How then can this legitimacy be maintained in the context of democracy with participation and opposition?

\subsection{Democracy in Indonesia Post 411 and 212}


Against that theoretical background, there is evidence that citizens feel alienated from their representatives at large. Many civil society activists have been detained because they participated in the movements against the government policies in posts 411 and 212, at the particular issues, such as the demonstrations against the Covid-19 Law, the Omnibus Law Bill, the HIP Bill, the Criminal Code Bill. The development of democracy in Indonesia, apart from the holding of general elections and local elections, leaves various problems. To take an example, in the last election of 2019 , marked by around 750 election workers have died. The tragedy of 21 and 22 May 2019 demonstrations in Bawaslu ended with the death of 10 citizens also happened. It was due to gunshot wounds and around 500 demonstration participants, including the Sarinah shopping center security guard who was detained. It is also evidence of the initial problem of forming a government resulting from the 2019 election as a source of legitimacy. On the one hand, the formation of a government is believed to be legal through elections. The development of democracy in this decade is interesting to discuss when 411 and 212 become attractive in the framework of several issues since the 2017 DKI regional election and continue with the 2019 election. First, the contestation of power has divided political and civil Islamic power groups with Islamophobic groups in the same sense large.

The Indonesian nation's construction is culturally diverse, both based on language, ethnic groups, and religious groups. Indonesia has the strength of these differences with the history of the colonial struggle carried out by nationalist figures, the kingdoms, Islamic sultanates that have existed since ancient times and have always fought against the Dutch. The construction of a pluralistic nation is the nation's strength and causes many issues that arise in contemporary political developments - the existence of development inequality in Java and outside Java. Then also, the dense population in Java and the less dense population outside Java causes the construction of representative democracy to be different, such as the number of representations of members of the DPR (Parliament), which are primarily from provinces in Java. It is because the DPR is a representative who represents people/populations.

Furthermore, this diversity can also be a source of conflict between minority groups and majority groups. However, it is somewhat different from the experience in various other countries, precisely in the economic context in Indonesia, minority groups control the wealth, land, and natural resources in Indonesia. Diversity has become a political jargon to marginalize Islamic groups in contemporary politics. Contemporary political issues today after the 411 and 212 movements are interesting to look at politics and how we see democratic politics in the future. The face of politics in Indonesia cannot be separated from the face of political Islam. How can we build nationalism in the current era of globalization? To what extent do global politics and economics affect the life of democracy in Indonesia? The extent to which questions such as the issue of political representation, regional autonomy, power relations between the executive-legislative-judicial, institutional buildings that fall into the category of state-auxcellaray institutions (such as the number of institutions with the name of commissions), exploitation of natural resources, curriculum problems in education, health, women, extreme violence, injustice etc. It is an important issue that becomes a challenge for the development of democracy in Indonesia. The answer to various issues is not easy. The political journey in Indonesia from the early 20th century to the early 21 st century is now needed to build a more just political-historical narrative of the building of the Indonesian nation. As a country with Indonesia's most prominent Muslim citizens, the ruling regime's policies often marginalize this Islamic group. Islam can be a solid factor in building national integration. Understanding Islamic groups make the building of nationality strong. In this discussion, the first view is to explain the sovereignty of the Indonesian nation. 


\subsection{Democracy, Islam and Politics}

In understanding the construction of the Indonesian nation, it can be seen the historical building of Indonesian sovereignty both as a nation-state and in the concept of understanding Indonesian nationalism:

First, cultural sovereignty, marked by the Youth Pledge on October 28, 1928, is one of the foundations. This pledge of boys and girls is a declaration of cultural sovereignty, having one homeland, one Indonesian homeland, one Indonesian nation, and one language of unity is Indonesian. This milestone of the youth pledge is a declaration of Indonesian culture because there is no Indonesian independence yet. We must respect the choice of the founders of this nation who have built cultural sovereignty in the building of the Indonesian state. What does it mean? Those female citizens are also involved in the construction process of the Indonesian state.

In the context of the founding fathers of the nation, the term founding father is often used (discrimination against the role of women), so it is necessary to upload a political history related to the Women's Congress on December 22, 1928. Political decisions at the Women's Congress held from 1928-1941 show the demands issues of education and women's rights both in the context of women's roles in the domestic and public spheres, including demands for the abolition of concubines in that era. Unfortunately, the Women's Congress was later commemorated on December 22 as Mother's Day at the Women's Congress in 1938. (see decisions of the women's congress 1928-1941). The role of women in building the Indonesian nation can be seen in the life history of the wives of national figures, many of whom took control of domestic affairs when their husbands fought for independence. The demands in this women's congress must be included in Indonesia's national history in the perspective of political roles towards a new Indonesian nationalism.

Second, political sovereignty, namely the independence of Indonesia, which was marked by the Proclamation of August 17, 1945. This independence in the context of the view of the Muhammadiyah Islamic group is referred to as Darul 'Ahdi wa syahadah. It is interesting to see from the perspective of this Islamic group so that the political narrative of nationalism and nationalism does not marginalize Islamic groups in the building of nationality. Pancasila state is the result of national consensus. BPUPKI Session May 29 - June 1, 1945, produced Pancasila and consensus on June 22, 1945, the Jakarta Charter. The Jakarta Charter combines the Five Precepts ideas with the ideas of Islamic groups, which in turn became an essential part in the opening of the 1945 Constitution, which was decided on August 18, 1945, at the PPKI (Indonesian Independence Preparatory Committee) meeting. The PPKI's decisions included ratifying the 1945 Constitution, which contained the state constitution, severing Soekarno-Hatta as President and Vice President, and forming KNIP to assist the President and Vice President.

Thus the political sovereignty marked by the independence of Indonesia is an important milestone in the history of being Indonesia. Political independence gives freedom to build the Indonesian nation. Of course, it is somewhat different from the concept of the nation-state developed in Western Europe. A nation is a political entity of the nationalist movement to fight for sovereignty, so the nation-state is a formation for that sovereignty. Nation in the context of Indonesia is built based on multiculturalism. The building consists of many ethnic groups, each of which has its territory. However, there are also immigrant groups that are the building blocks in the context of citizenship. In the Dutch colonial era, social discrimination regarding race in Indonesia was divided into three categories, namely first European (Dutch and white), second eastern foreign race (including Chinese, Arab, Indian, and other 
Europeans), and third Inlander (which translates as native). This social discrimination is then still attached to the day we are familiar with the terminology of indigenous and nonindigenous people. Using the model of liberal thinking in looking at the problems of majority and minority in a political context is not enough to explain the overall relationship between economics and politics in Indonesia. Making minority groups victims also needs to be seen more broadly in the context of representation, economic control, land tenure, natural resource control, access to education, access to health.

Third, territorial sovereignty, which was marked by the Djuanda Declaration on December 13, 1957. Djuanda Kartawidjaya was the Prime Minister of Indonesia. This declaration is fundamental as the country must have straightforward territorial claims. This Djuanda Declaration states that the Indonesian sea area includes the surrounding seas between and within the Indonesian archipelago to become one unitary territory of Indonesia. Indonesia claims territory is a Dutch colony. In the Dutch East Indies Ordinance of 1939, the sea area was only 3 miles from the coastline.

The Djuanda Declaration reinforces the principle of an archipelagic state, that Indonesian seas are not free seas. The declaration was later strengthened into Law No. 4/PRP/1960. In 1982, in the third UN Law convention, this declaration was recognized by the United Nations Convention on the Law of the Sea. Then it was updated by the Indonesian government in Law no 17/1985. Can we imagine if the Java Sea became a international sea? With this, territorial sovereignty becomes the building of a complete state. However, it is necessary to get attention to keep Papua within the territory of the Indonesian state with a more people-centered paradigm approach, not a state-centered paradigm. How to prosper the Papuan people and all Indonesian people to defend the Republic of Indonesia is essential. This cultural, political, and territorial sovereignty must be complemented by economic sovereignty and the sovereignty of the dignity of the Indonesian nation.

From this series of historical narratives of the construction of the nation and state of the Republic of Indonesia, which before August 17, 1945, were Islamic kingdoms or sultanates from Aceh to Tidore, we can learn. With a powerful history of Islam in the Republic of Indonesia before independence, it is ironic that in contemporary politics today, the political power of Islam is marginalized. There are even accusations that Islamic political forces are trying to replace Pancasila. Meanwhile, its supporters are considered intolerant, not diverse, and not a pluralist. The contribution of Islam in building the Republic of Indonesia is enormous. All the kingdom territory, its wealth, and sovereignty were handed over to the new state of the Indonesia Republic. The understanding of Indonesian unity is actually based on the same strength, namely Islam. Because Islamic religious beliefs, which became the primary motor driving resistance against the Dutch colonialists. In today's political developments, Islamic politics has become increasingly complex with global politics.

\subsection{Global Politics}

In this era of globalization, Indonesia is in between a war on terror policy and a democratization process. In a global position, the problems that arise are often related to neocolonialism. The control of existing natural resources is not for the welfare of all Indonesian people as in the Fifth Precepts of Pancasila. As a country with the most prominent Muslim citizens globally, rich in natural wealth, a country with a large territory and a large population. Indonesia has become a global power struggle. The control of wealth in small groups due to policies since the Dutch era and continued by Soekarno and Suharto has impacted contemporary politics. The Suharto regime did not provide room for political participation in 
the Chinese group but gave ample space to build economic power by building collusion and nepotism. As a result, currently, politics is very open; unfortunately, it is more liberal with economic power that regulates and is also directly involved in political contestation. Elections are more colored with money politics. Elections and Regional elections are more about buying votes than contesting the program in a free and fair manner. In addition, the power of the media is controlled freely (no cross-media ownership policy), as well as currently in the digital era with the use of social media in campaigns. Friedman stated that the combination of economic and political power, on the one hand, would make the recipe for tyranny easy. (see Milton Friedman).

What about global power? How to communicate with Washington America? How about talking to the Chinese government, which is developing a one belt one root policy? In the last two hundred years, the data on economic control has made economic liberalism the only economical option that can prosper the people. The data in Indonesia itself is $74 \%$ of land ownership by only $1 \%$ of the Indonesian population, $49 \%$ of Indonesia's wealth is controlled by one percent of citizens (see the book Paradox Indonesia).

Another issue in global politics is ISIS. After the collapse of the USSR, Islam became an issue that continued to be developed. The wars in Iraq and Iran, political changes in the Middle East, and now ISIS. In Indonesian politics, Islam is embedded with radical/extremist terminology to become demons (demonization of Islam), both movements seeking justice in extreme ways and engineering radical Islamic movements in Indonesia. There was the concept of demonization of Javanese outside Java; now, we face the demonization of extremist Islam, with the definition according to the ruling regime. Thus the portraits of civil Islam 411 and 212 are perceived as radical Islam and are afraid to build an Islamic state in Indonesia.

\subsection{Democracy in Indonesia: the conflict of legitimacy}

Democracy in Indonesia are we on the right track? Discussing democracy, we can at least use the definition from Diamond, Lipset which states that in a democratic government, there are three elements, namely there is competition but excluding the use of force; full participation, no citizen should be marginalized in the political process, whether appointed or elected; and civil and political liberties.

In the context of building competition between political forces, especially political parties, this nation must pay attention. Political parties are significant institutions in the life of the state. However, political parties are often hated, corrupted, build dynasties, unable to work, etc. The problem is first, the problem of internal party democracy; in the theory of organizational oligarchy, the power of the general chairman is still decisive, the succession of party management democracy is still heavily colored by money politics, the ruling regime is often anti-competition with the strategy of divide et impera in the management of political parties. Political parties themselves are still very strongly dependent on "political dealers" who finance these political parties so that political parties are trapped in rent-seekers. The function of political parties is for the recruitment of political positions, political education, political communication, and what often gets less attention is policy formulation and policy implementation. Political parties eventually recruit those who have capital. Thus, political parties become pragmatic to gain power (power struggle/power over, not power to do). Strengthening political parties through their cadres and developing party ideology and state ideology in selecting social, economic, and political policies is very important. Political parties are still strong but only become vehicles (political vehicles) to gain power. Political parties can be known to the lowest constituent level, namely the people at the village level, through 
autonomous institutions or under bow organizations. Building youth, women's, and other professional organizations are important for strengthening these political parties.

The principle of elections is free and fair. The 2004 election model should be an important history for the Indonesian nation. This is the first time in history that direct presidential and vice-presidential elections have been held. At the same time, elections with a purely limited open system. It was the first time that regional representatives were directly elected, including direct regional elections. After four elections in this reform era, a more comprehensive evaluation of the electoral system is needed. Both those related to the administration politics of the election administration and those related to direct regional elections at the district/city level. The direct election model does not provide well for the people.

The indicator of full participation can be linked to the issue of affirmative action for female candidates. With significant participation of women can be involved in the formulation of more gender-friendly policies. Women's specific issues related to reproductive rights, gender relations issues, violence against women, and lower political issues such as education, health, migrant workers, etc., can be an issue that is discussed in political policy more openly.

Meanwhile, civil and political liberties, freedom of association, freedom of the press, and freedom of expression are important parts of democracy. Especially about the partisan role of the media and often more towards the media, "he said," in every time he delivered political news. Media control is only in a few figures. The role of civil society in democracy is very central. Civil society is always a force to criticize the authorities, both legislative and executive. The building of democracy is marked by opposition forces, both opposition within parliament and opposition outside parliament. Civil society can be an opposition force outside parliament. The use of violence in competition, in this case, the use of verbal violence through buzzers and the arrest of figures who are considered oppositional by using articles of law, and the murder of 6 FPI soldiers and the disbandment of civil society organizations such as the FPI show that the principle of civil and political liberties can lead to democracy flaws.

\subsection{Regime Legitimacy: C-19 Pandemic, Km 50 Case, detention of activists and Ulama}

The Covid-19 pandemic has turned political forces around the world and local politics upside down. World leaders have shown the extent of their ability and capacity to manage the COVID-19 pandemic in protecting their citizens: the ability to plan, leadership, policy in dealing with the Covid-19 Pandemic. Leaders who do not have leadership skills, empathy, and political communication are very clearly seen in handling the Covid 19 pandemic, regulations, policies taken, vaccine management, and education issues in the era of the $\mathrm{C}-19$ pandemic. In Indonesian politics, the ruling regime does not have a leadership that can provide a clear direction in dealing with the $\mathrm{C}-19$ pandemic.

The issuance of Law No. 2 of 2020 concerning state financial policies for handling the Corona Virus Disease-19 Pandemic happened. The stipulation of Perpu (Law replacement) in Replacing Law No. 1 of 2020 concerning State Financial Policy and Financial System Stability for the Handling of the Covid-19 Pandemic and in the face of threats that endanger the national economy, financial system stability becomes a law. What is in it? The law's title alone is more towards 1) state financial policy; 2) state financial stability; 3) financial system for handling Covid-19. However, there was no significant debate in the DPR. However, the DPR is a political force that has the function of controlling the government. From Perpu No. 1 of 2020, there is no compelling urgency, state finances, and Covid-19. In the context of democracy, the President takes the DPR's authority, which can lead to arbitrary actions. 
The law does not have an instrument for handling Covid-19. In the Republic of Indonesia, two laws can be used: the Health Law, Law No. 6 of 2018, and the Disaster Law No. 24 of 2007. This law contains articles used by regimes that are outside of democratic principles. For example, in article 27 in paragraphs 1,2, and 3, the use of finance will not be included as a category of state losses. Officials cannot be prosecuted criminally and civilly as long as there is 'good faith and obedience to the law. The implementation of this law is not the object of a lawsuit to be in the Administrative Court.

Unfortunately, many state policies regarding handling the Covid-19 pandemic consider not paying attention to social problems properly. Especially for those who fall into the category of poor people, it has affected daily workers, education issues (online) lack clarity on planning. Policies that change but do not improve still appear, such as PSBB, PPKM, limited PPKM, and PPKM levels. Meanwhile, Indonesia is one of the countries with the most victims of health workers who died due to the Covid-19 pandemic. In addition, hospital administration and vaccines and drugs include the availability of special rooms and the limited availability of oxygen. There are multi-dimensional national problems, namely social, economic, political. Social conditions in the context of a divided nation have not been improved. Meanwhile, economic conditions show that the state's wealth is controlled by a small group (economic oligarchs). It can trigger a political crisis: political change and government succession with much electoral manipulation (the liberal machiavelian election). At the same time, the use of rhetoric is causing the nation to divide with Islamophobic propaganda. The exploitation of natural resources to benefit the palace elite political group with the presence of many foreign workers in waves from China happened.

Meanwhile, in Indonesia, there is a mix between the unclear handling of the Covid-19 pandemic in the political sphere, with many important figures from the opposition forces being imprisoned. It is an irony since the 2019 election process caused many election workers to die and people who were shot and detained. Then the arrest of Syahganda, Jumhur Hidayat,

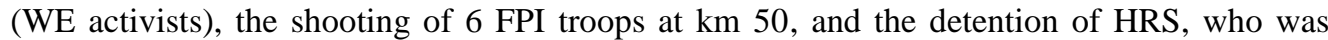
arrested and detained because of the health protocol case. Then it was followed by a long process of the HRS trial, which was colored by much irony. The arrests of the critics became the face of a "democracy" that could be considered flawed. HRS became a political opponent of the regime with a series of cases raised and the shooting of 6 FPI troops who were on duty to guard HRS. The trial was held with a real show of injustice. Meanwhile, conventional media does not provide balanced coverage. HRS, which is not from a political party whose organization is FPI, was dissolved by the regime unilaterally, showing that the ruling regime has violated democratic principles.

As the head of the FPI society organization, HRS is actually not the only Islamic organization in Indonesia. The dominant Islamic mass organizations in Indonesia are Muhammadiyah and NU. However, in the 2014 and 2019 election results, it must be admitted that there are policies that show hostility to Islamic political forces. FPI's firm position in the DKI Pilkada (Regional election), which gave non-Muslim BTP candidates, became a major concern. Moreover, blasphemy, namely the Al Maidah 51 incident, which was carried out by the governor of DKI, triggered the movement of Islamic political power through the 411 and 212 movements.

BTP has insulted the Qur'an Surah Al Maidah verse 51 during the campaign in the 2017 DKI Jakarta gubernatorial election. The 411 and 212 movements are known as the Islamic Defense Action, and FPI became one of the pioneers with HRS leadership in the National Movement to Guard Fatwa MUI (GNPF MUI). With the stipulation of BTP as a convict with a sentence of 2 years in prison, HRS becomes a disturbing figure. He is considered disturbing 
the comfort of the oligarchic economic forces and colludes with the political oligarchs. This political force - civil Islam - worked to prove support for Anis Baswedan to win the DKI regional election. The Islamic civil movement worked with extraordinary awareness to maintain the ummah's voice in the DKI regional election.

The position mentioned above continues with the 2019 election; social forces (civil Islam) try to continue with the movement to replace the president and Ijtima 'Ulama. However, the power of civil Islam has not been able to defeat the power of the regime that uses the state power structure. The use of state apparatus to defend the incumbent cannot be stopped, including the formation of a winning task force to the village level; the use of superior programs such as village funds to maintain power, conventional media support and social media buzzers that are apparently paid for, survey institutions that function as opinion leaders. All of them show the contestation of political power with their respective supports. The tragedy of hundreds of election workers died, and ten were shot, 500 people were arrested in the tragedy of 21 and 22 May 2019 in front of Bawaslu; apparently, the post-election continued.

The Covid-19 pandemic, the health care policy, the return of HRS from exile, the disbandment of FPI, the KM 50 case, the arrest of activists who voiced criticism, all of which are examples of post-election regime oppression. The legitimacy of winning the 2019 election results is not sufficient for the regime to consolidate democracy. This is because the ruling regime and its supporting forces are already interlocking to maintain their power in the 2024 election. The issue of amendments to the 1945 Constitution to open a three-term presidential term is one of the proofs. The contestation of civil Islam will always be an important part of politics in Indonesia as long as the ulama' and civil Islam figures still exist.

\section{Conclussion}

The legitimacy of the ruling regime can not only be obtained through elections. Policies issued by the government that is considered valid from the election results are still being monitored. In a democracy, the opposition is needed. Repression against opposition groups will affect the legitimacy of the ruling regime. If policies such as the handling of the Covid-19 pandemic, the use of the Covid budget, the issue of Covid data, the issue of logistical corruption for residents affected by Covid do not defend the interests of the people at large, then the legitimacy of power will be unstable. In addition, the enactment of the Omnibus Law, which gives state officials the freedom to exploit forests and mines and invites many foreign workers from China, provides a source of legitimacy conflicts. The arrest of Ulama' such as HRS and others, made public trust in the authorities low.

Meanwhile, the parliamentary opposition was co-opted into supporting the regime. The whole series of governance of this regime will gradually collapse the level of legitimacy in building this democracy. Regimes in power because of dishonest, not free, and fair elections will use their power to maintain their legitimacy. Legitimacy can be built if the implementation of the policies taken defends the interests of its people. Legitimacy also requires leaders who can govern well. The most important thing is that legitimacy requires the support of social, economic, and political policies outlined in regulations and in their implementation to defend the interests of the nation and state following the constitutional mandate of the 1945 Constitution, especially in the Preamble. The mandate of the opening of the 1945 Constitution is to defend all of Indonesia's bloodshed, educate the nation's life and 
prosper the Indonesian people and participate in the world order for justice. The constitution is a sacred agreement and agreement together in building the country.

\section{References}

[1] Dahl, R, Poliarchy: Participation and Opposition (New Haven:, CT: Yale University, 1971.

[2] Diamond, L., Linz and S. Lipset,(eds.), Democracy in Developing Countries, (Boulder, CO: Lyne Rienner), 1989.

[3] Diamond, Larry, Developing Democracy, Baltimore: John Hopkins University Press, 1999.

[4] Fukuyama, Francis, The End of History and the Last Men, Free Press, 1992.

[5] Huntington, S., Third Wave: Democratisation in the late Twentieth Century, (Norman, Okla. And London: university of Oklahoma Press, 1991.

[6] The Clash of Civilisations and the making of World Order (New York: Oxford University Press, 1996.

[7] Haddad and Esposito, Islam, Gender and Social Change, Oxford: Oxford University Press, 1998.

[8] Saliba, Therese, Carolyn Allen and Judith A. Howard (eds.), Gender, Politics, and Islam, Chicago: University of Chicago Pers, 2002. 